\title{
Bilateral graft emphysematous pyelonephritis
}

\author{
Shanmugasundaram Rajaian, Murugavaithianathan Pragatheeswarane, \\ Karrthik Krishnamurthy, Lakshman Murugasen
}

MIOT International, Chennai, Tamil Nadu, India

Correspondence to Dr Shanmugasundaram Rajaian, ssrl25@gmail.com

SR and MP contributed equally.

Accepted 3 June 2019
Check for updates

(c) BMJ Publishing Group Limited 2019. No commercial re-use. See rights and permissions. Published by BMJ.

\begin{tabular}{|l|}
\hline To cite: Rajaian S, \\
Pragatheeswarane M, \\
Krishnamurthy K, et al. BMJ \\
Case Rep 2019;12:e231051. \\
doi:10.1136/bcr-2019- \\
231051
\end{tabular}

\section{DESCRIPTION}

Emphysematous pyelonephritis (EPN) in a postrenal transplantation state is a rare condition and associated with high morbidity. ${ }^{12}$ Conservative management with antibiotics and percutaneous drainage is successful in majority of the patients, ${ }^{3}$ but severe forms of disease at presentation carries high mortality. ${ }^{2}$ A 44-year-old male patient presented with history of breathlessness and fever with chills of 1 -day duration. He is known to have diabetes, hypertension and coronary artery disease. $\mathrm{He}$ underwent live-related renal transplant in 2005, which got rejected in 2017. He had second live-related renal transplant in 2017 , which also got rejected due to chronic pyelonephritis. He was on maintenance haemodialysis for the past 3 months. On examination, he had fever of $39^{\circ} \mathrm{C}$, pulse rate of $120 / \mathrm{min}$ and blood pressure of $90 / 60 \mathrm{~mm} \mathrm{Hg}$. He had lower abdomen tenderness, and the rest of the examination was normal. His blood investigations revealed total count of $24.5 \times 10^{9}$, random blood sugar-342 $\mathrm{mg} / \mathrm{dL}$, serum creatinine $-5.2 \mathrm{mg} / \mathrm{dL}$, haemoglobin- $72 \mathrm{~g} / \mathrm{L}$, while rest of the parameters were normal. Escherichia coli was grown from the urine culture. He underwent CT scan of the abdomen which revealed bilateral emphysematous graft pyelonephritis with air in the bladder (figure 1). He was catheterised with 18 Fr Foley, which drained $50 \mathrm{~mL}$ of purulent urine. He was started on injection meropenem $500 \mathrm{mg}$ intravenously two times per day and insulin on sliding scale basis, but his clinical condition did not improve even after 24 hours. He underwent early bilateral subcapsular graft nephrectomy (figure 2). Culture of tissue from phlegmon has also grown E. coli. He was on maintenance haemodialysis in the postoperative period. His postoperative period was uneventful, and he was discharged in stable condition on the fifth postoperative day.

EPNs affecting transplant kidneys are rare with only 29 cases reported in the literature. ${ }^{4}$ Clinical presentation is also subdued due to denervated graft kidneys and immunosuppressive state. ${ }^{4}$ Uncontrolled diabetes and immunosuppressive drugs

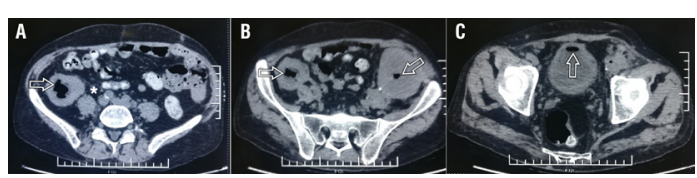

Figure 1 (A) CT scan revealing gas in right kidney (hollow arrow) and perinephric fat stranding (asterisk). (B) CT scan depicting gas in the bilateral renal pelvis (hollow arrow). (C) CT scan revealing gas in the urinary bladder (hollow arrow).

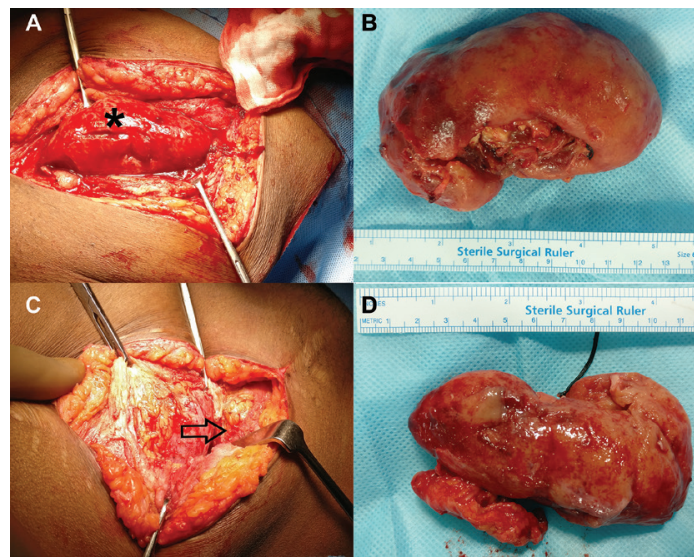

Figure 2 (A) Intraoperative picture of right kidney with pus flakes (asterisk). (B) Gross specimen of right subcapsular nephrectomy. (C) Intraoperative picture of phlegmon surrounding left kidney (hollow arrow). (D) Gross specimen of left kidney with adherent phlegmon.

makes this population more susceptible for allograft infection. Allograft EPN is associated with higher mortality, graft loss and permanent dialysis. ${ }^{4} \mathrm{CT}$ is the gold standard for diagnosing this condition, and different management algorithms are proposed. ${ }^{4}$ Newer staging system as proposed by Al-Geizawi has taken both anatomical and septic components of the disease process into account for the management guidelines. ${ }^{1}$ Recent studies have shown that medical management with percutaneous drainage have the lowest complication and increased chances of graft salvage. ${ }^{5}$ In our case as the patient was already on maintenance haemodialysis for chronic allograft rejection, we did not attempt for double J stenting or percutaneous drainage. Though conservative management with antibiotics and percutaneous drainage is successful in majority of the patients, ${ }^{3}$ severe forms of disease at presentation carry a high mortality even when nephrectomy is performed. ${ }^{2}$ As the literature regarding EPN in graft kidneys is scarce, the patient's clinical signs and severity of presentation should decide the line of

\section{Learning points}

Percutaneous drainage and intravenous antibiotics are acceptable treatment options, but in severe cases or those refractory to treatment, nephrectomy is the appropriate treatment.

- Treatment should be individualised as the literature and guidelines are scarce. 
management rather than strictly adhering to a grading system. ${ }^{2}$ We conclude that a higher grade of disease staging at presentation should have a lower threshold for performing nephrectomy to reduce mortality.

Contributors SR and LM examined the patient and collected data. MP conceptualised and designed the study and written the manuscript. KK analysed and reviewed the manuscript.

Funding The authors have not declared a specific grant for this research from any funding agency in the public, commercial or not-for-profit sectors.

Competing interests None declared.

Patient consent for publication Obtained.

Provenance and peer review Not commissioned; externally peer reviewed.

\section{REFERENCES}

1 Al-Geizawi SM, Farney AC, Rogers J, et al. Renal allograft failure due to emphysematous pyelonephritis: successful non-operative management and proposed new classification scheme based on literature review. Transpl Infect Dis 2010;12:543-50.

2 Oliveira CC, Garcia PD, Viero RM. Emphysematous pyelonephritis in a transplanted kidney. Autops Case Rep 2016;6:41-7.

3 Aswathaman K, Gopalakrishnan G, Gnanaraj L, et al. Emphysematous pyelonephritis: outcome of conservative management. Urology 2008;71:1007-9.

4 Etta P, Rao MV. Emphysematous pyelonephritis in a renal allograft. Indian I Transplant 2018:12:59-61.

5 Somani BK, Nabi G, Thorpe P, et al. Is percutaneous drainage the new gold standard in the management of emphysematous pyelonephritis? Evidence from a systematic review. J Urol 2008;179:1844-9.

6 Aboumarzouk OM, Hughes $\mathrm{O}$, Narahari K, et al. Emphysematous pyelonephritis: Time for a management plan with an evidence-based approach. Arab J Urol 2014;12:106-15.

Copyright 2019 BMJ Publishing Group. All rights reserved. For permission to reuse any of this content visit

https://www.bmi.com/company/products-services/rights-and-licensing/permissions/

BMJ Case Report Fellows may re-use this article for personal use and teaching without any further permission.

Become a Fellow of BMJ Case Reports today and you can:

- Submit as many cases as you like

Enjoy fast sympathetic peer review and rapid publication of accepted articles

- Access all the published articles

Re-use any of the published material for personal use and teaching without further permission

Customer Service

If you have any further queries about your subscription, please contact our customer services team on +44 (0) 2071111105 or via email at support@bmj.com.

Visit casereports.bmj.com for more articles like this and to become a Fellow 